\title{
Spontaneous Esophagus Perforation: A Rare Case
}

\author{
Yahya Kemal Günaydın', Mustafa Çalık², Can Gökay Yıldız', Nazire Belgin Akılı', Ramazan Köylü', Hıdır Esme², Başar Cander \\ 'Department of Emergency Medicine, Konya Training and Research Hospital, Konya, Turkey \\ ${ }^{2}$ Clinic of Thoracic Surgery, Konya Training and Research Hospital, Konya, Turkey
}

\begin{abstract}
Boerhaave's syndrome (spontaneous esophageal rupture) is a rare entity, which is characterized by a rare and late diagnosis. It is a life-threatening condition and requires early diagnosis and urgent care. The most common etiological factor is emesis. A history of forceful emesis, subxiphoid chest pain, and subcutaneous emphysema is a common triad of symptoms that should suggest spontaneous rupture of the esophagus. However, sometimes confused other diseases that chest pain such as myocardial infarction, aortic aneurysm, pulmonary embolism, pneumothorax. In this report, we aim to present a patient who was diagnosed with the Boerhaave's syndrome. In addition, we will also review the usual presenting signs, symptoms, and treatment of the Boerhaave's syndrome.

(Eurasian J Emerg Med 2015; 14: 157-9)
\end{abstract}

Keywords: Esophagus, vomiting, perforation

\section{Introduction}

Boerhaave's syndrome (spontaneous esophageal rupture) is a rare entity, which is characterized by a rare and late diagnosis. It is commonly misdiagnosed as peptic ulcer perforation, myocardial infarction, pulmonary embolism, aortic aneurysm, and dissection and pancreatitis (1). It is a life-threatening condition and requires early diagnosis and urgent care. Boerhaave's syndrome is characterized by the full layer and vertical tear at the cardioesophageal junction of the esophagus, following heaving and vomiting, and results from the sudden rise in intraluminal pressure in the distal esophagus (2, 3). Here, we presented a patient with Boerhaave's syndrome that is rarely seen and reviewed the diagnostic tools and treatment options in our report.

\section{Case Presentation}

A 53-year-old male patient presented to our emergency department with severe chest and abdominal pain radiating to his back, following sudden vomiting after eating a meal. He was quite agitated during the physical examination. His vital signs revealed blood pres- sure readings of $140 / 90 \mathrm{mmHg}$ and $130 / 80 \mathrm{mmHg}$ in the right and left arms, respectively. The other physical parameters were as follows: pulse, 96 beats $/ \mathrm{min}$; fever, $37^{\circ} \mathrm{C}$; and oxygen saturation, $98 \%$. The patient was conscious, well-oriented, and cooperating. The respiratory and cardiovascular system examinations were normal. Widespread abdominal pain existed, without abdominal guarding and rebound tenderness. Neurological examination was normal. No previous disease or drug history was present.

In his tests, the electrocardiogram showed sinus tachycardia. The leukocyte count was $20000 \mathrm{~K} / \mathrm{uL}$, with other cardiac enzymes, D-dimer, and biochemical tests being normal. His chest X-ray showed suspicious air bubbles surrounding the trachea and in the mediastinum (Figure 1). Prediagnoses of aortic dissection and peptic ulcer perforation were suspected, and thoracic and abdominal computed tomography (CT) with IV contrast was performed. Air densities, compatible with the pneumomediastinum seen in the paraesophageal region, with prominence in the paraaortic area were detected in tomography (Figure 2). Esophagography was performed because of the suspicion of esophageal perforation, and it detected a distal end esophageal perforation. The patient was consulted by the thoracic surgeons and was operated. No complication occurred. The patient

Correspondence to: Yahya Kemal Günaydın e-mail: gsykg@yahoo.com

Received: 18.02.2015 Accepted: 08.06.2015

(C) Copyright 2015 by Emergency Physicians Association of Turkey - Available online at www.eajem.com

DOI: 10.5152/eajem.2015.04695 


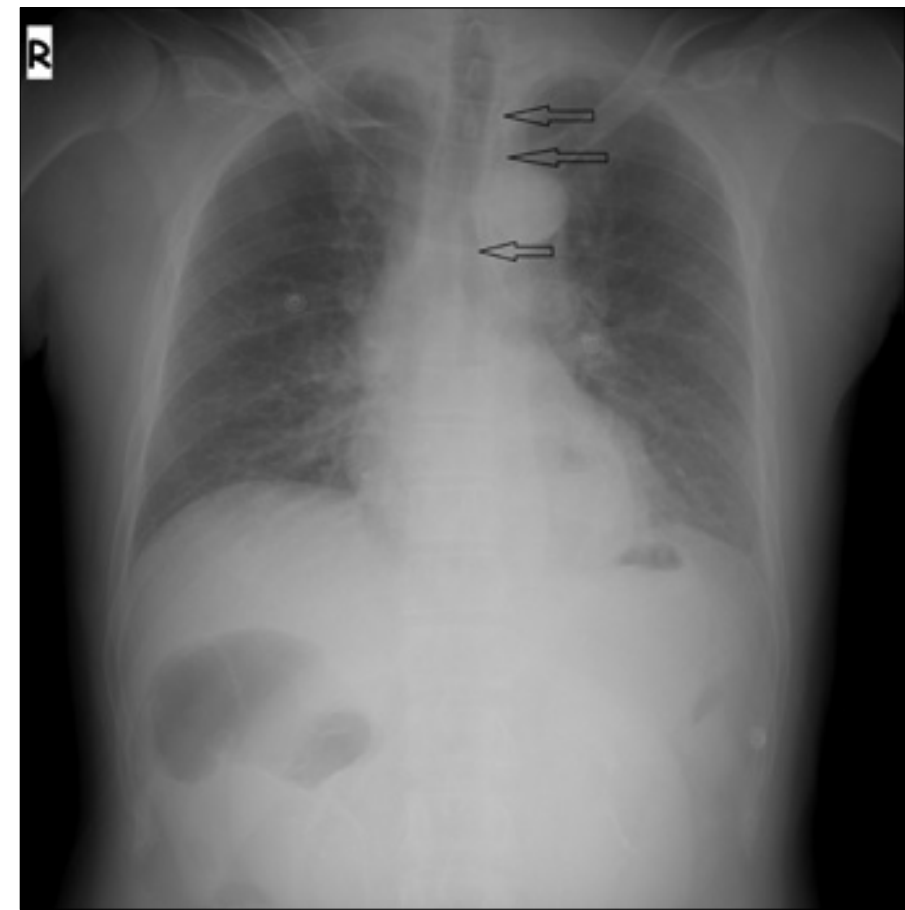

Figure 1. Chest radiography

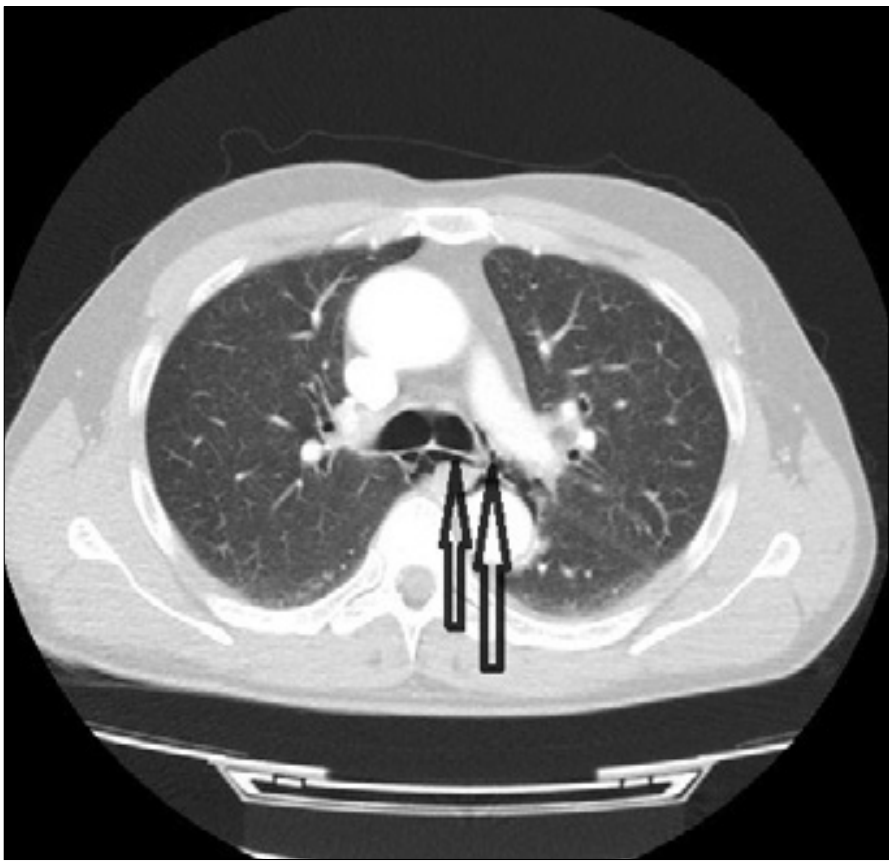

Figure 2. Thoracic computed tomography

was discharged after 10 days with total recovery, following postoperative intensive care and service care (Figure 3).

\section{Discussion}

Boerhaave's syndrome was first defined by a Dutch physician, Boerhaave, in 1704. It is five times more common in men than in women. It is most frequently seen after vomiting and heaving etiologically and less frequently seen after stretching, giving birth, severe coughing, blunt trauma, epilepsy, asthma, and difficult swallowing (4).

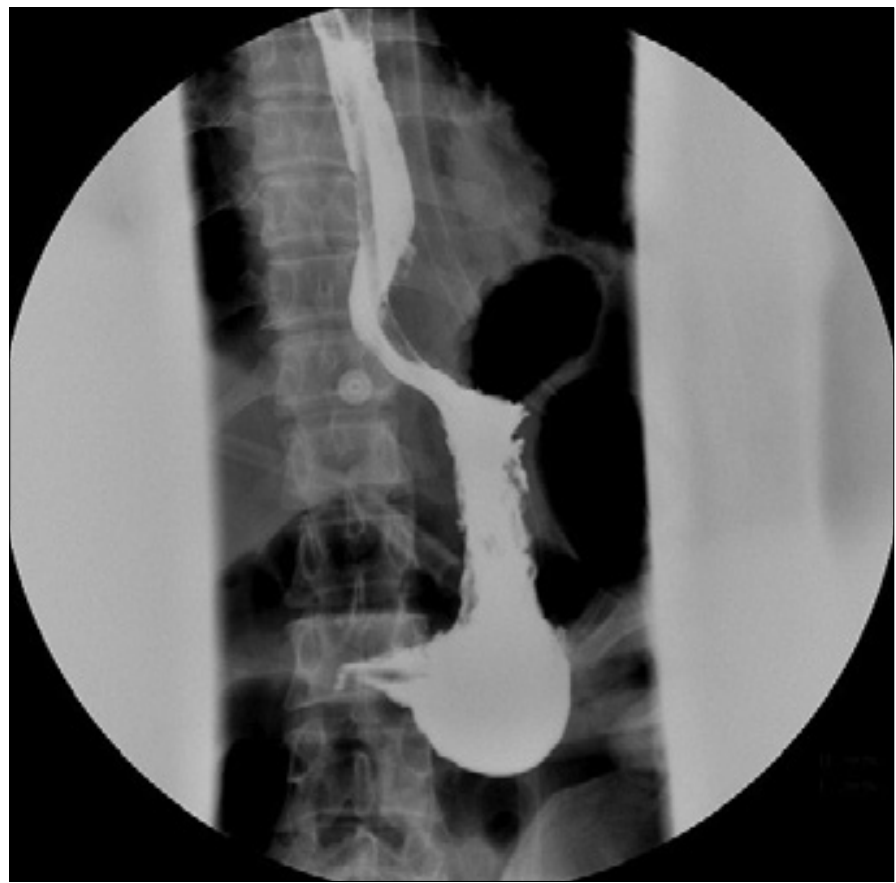

Figure 3. Esophagography

In our patient, the patient was 53 year old male patient, compatible with the literature, and applied to our emergency department with the told clinic.

Because the esophagus does not have a serosa layer, it can be prone to low pressure and rupture compared with the other parts of the gastrointestinal system. The distal diameter of the esophagus may increase to 5 times or more of its original diameter during vomiting. The negative intrathoracic pressure increase during vomiting creates a convenient environment for rupture by making sudden changes in the lumen diameter (4).

The findings in most of these patients are atypical, causing a late diagnosis or misdiagnosis. It is rarely diagnosed in $24 \mathrm{~h}$ (5). In our patient, the diagnosis was made in the first $6 \mathrm{~h}$ and the patient was operated.

This rupture occurs in the distal 1/3rd part of the esophagus and in the left lateral position in $90 \%$ of the patients (6). It was the same in our patient. If the lesion includes all the layers of the esophagus, it is called Boerhaave's syndrome, whereas if it only includes the mucosal layer, it is called the Mallory-Weiss syndrome $(7,8)$.

The anamnesis, physical examination, and radiological examination are crucial for the diagnosis of esophagus perforation. A delay in the diagnosis and treatment may cause purulent mediastinitis, pleuritis, sepsis, and death. The most important criteria to survive esophageal perforation are early diagnosis and early and appropriate treatment (9). The pain occurring simultaneously with vomiting or just after vomiting is crucial for diagnosis. Epigastric distress, discomfort, and rebound tenderness may be present in the patients. Septic shock generally occurs following the first $12 \mathrm{~h}$ (10). X-ray graphs in the diagnosis of esophageal perforations give important clues in 70\%-90\% of the cases. Findings such as hydrothorax, pneumothorax, hydropneumothorax, pneumomediastinum, subcutaneous emphysema, mediastinal expansion, subdiaphragmatic air, foreign body, and retrotracheal expansion may be found $(11,12)$. Esophageal perforation should be suspected immediately in the presence of a mediastinal emphysema in a chest X-ray. If the rupture cannot be observed with 
the abovementioned radiological methods, a CT with oral contrast solution is performed. The definite diagnosis of the rupture is its endoscopic presentation. With the esophagoscopy, both the level of the rupture and the accompanying diseases are detected as well as the treatment option is chosen $(13,14)$.

Despite the progress in the intensive care treatments, the esophageal perforations still have a mortality rate of more than $20 \%$. The untreated cases have a mortality rate between $20 \%$ and $40 \%$. A close relationship was found between the period of the onset of the symptoms and the initiation of the treatment and the mortality. The mortality is generally observed following mediastinitis, pneumonia, pericarditis, and empyema $(6,15)$.

Medical or surgical treatments are available. If it is a closed perforation, no mediastinitis is observed, and the patient is stable, medical treatment can be chosen. The medical treatment includes drainage, intravenous antibiotics, nasogastric decompression, and enteral nutrition. If the patient is unstable, a clinically important mediastinitis is present, and there is open perforation, surgical treatment should be chosen (16).

\section{Conclusion}

Spontaneous esophageal perforation prognosis differs according to the early diagnosis and appropriate treatment. It should be known that early diagnosis and treatment contributes to a decrease in mortality rates. The emergency physician should think of Boerhaave's syndrome in the presence of sudden chest pain and subcutaneous emphysema, following heaving and vomiting.

Informed Consent: Patient consent could not be obtained. Because the patient had a life-threatening and was taken to emergency surgery. It was therefore not in a position to give consent.

Peer-review: Externally peer-reviewed.

Conflict of Interest: No conflict of interest was declared by the authors.

Financial Disclosure: The authors declared that this study has received no financial support.

\section{References}

1. Teh E, Edwards J, Duffy J, Beggs D. Boerhaave's syndrome: a review of management and outcome. Inter Cardiovasc Thoracic Surg 2007; 6: 640-3. [CrossRef]

2. Lorne H. Blackbourne M.D., F.A.C.S. Trauma, Burn and Critical Care Surgeon Surgical Recall. In Lorne H. Blackbourne M.D., F.A.C.S Editor. Maryland: 6th ed. San Antonio, Texas: Lippincott Williams \& Wilkins; 2006. p. 33-7.

3. Korn $\mathrm{O}$, Oñate JC, López R. Anatomy of the Boerhaave syndrome. Surgery 2007; 141: 222-8. [CrossRef]

4. Curci JJ, Horman MJ. Boerhaave's syndrome: The importance of early diagnosis and treatment. Ann Surg 1976; 183: 401-8. [CrossRef]

5. Wolfson D, Barkin JS. Treatment of Boerhaave's syndrome. Curr Treat Options Gastroenterol 2007; 10: 71-7. [CrossRef]

6. de Schipper JP, Pull ter Gunne AF, Oostvogel HJ, van Laarhoven CJ. Spontaneous rupture of the oesophagus: Boerhaave's syndrome in 2008. Dig Surg 2009; 26: 1-6. [CrossRef]

7. Rochford M, Kiernan TJ. Images in emergency medicine, Boerhaave's syndrome (spontaneous esophageal rupture). Ann Emerg Med 2007; 49: 746-77. [CrossRef]

8. Griffin SM, Lamb PJ. Spontaneous rupture of the oesophagus. Br J Surg 2008; 95: 1115-20. [CrossRef]

9. Asensio JA, Chahwan S, Forno W, Mackersie R, Wall M, Lake J, et al. Penetrating esophageal injuries: multicenter study of the American Association for the Surgery of Trauma. J Trauma 2001; 50: 289-96. [CrossRef]

10. Özçelik C, İnci I. Özofagus yaralanması. In Yüksel M, Başoğlu A. ed. Özofagus Hastalıklarının Tıbbi ve Cerrahi Tedavisi. 2002. p. 77-108.

11. Eckstein M, Sean O. Henderson. Thoracic trauma, Esophagus perforation. In Marx J A, ed. Rosen's Emergency Medicine. Concepts and Clinical Practice 8th ed. Philadelphia: Mosby; 2014. p. 455-8.

12. Ghahremani G. Esophageal trauma. Semin Roentgenol 1994; 29: 387400. [CrossRef]

13. Ochiai T, Hiranuma S, Takiguchi N, Ito K, Maruyama M, Nagahama T, et al. Treatment strategy for Boerhaave's syndrome. Dis Esophagus 2004; 17: 98-103. [CrossRef]

14. Fadoo F, Ruiz DE, Dawn SK, Webb WR, Gotway MB. Helical CT esophagography for he evoluation of suspected esophageal perforation or rupture. AJR Am J Roentgenol 2004; 182: 1177-9. [CrossRef]

15. Huber-Lang M, Henne-Bruns D, Schmitz B, Wuerl P. Esophageal perforation: principles of diagnosis and surgical management. Surg Today 2006; 36: 332-40. [CrossRef]

16. Amir Al, van Dullemen $\mathrm{H}$, Plukker JT. Selective approach in the treatment of esophageal perforations. Scand J Gastroenterol 2004; 39: 418-22. [CrossRef] 